\title{
PENGARUH KEBIASAAN MEROKOK TERHADAP OBESITAS DAN OVERWEIGHT PADA KARYAWAN UNIVERSITAS DI JAKARTA
}

\author{
Dewi Indah Lestari \\ Fakultas Kedokteran Universitas Tarumanagara, DKI Jakarta \\ dewil@fk.untar.ac.id
}

\begin{abstract}
ABSTRAK
Obesitas dan overweight merupakan masalah kesehatan mayor saat ini karena meningkatkan angka mortalitas.Obesitas ini merupakan faktor komorbid bagi penyakit lain seperti diabetes tipe2, penyakit jantung, gangguan hati, hipertensi, stroke, kanker. Adapun faktor risiko adalah gaya hidup seperti kebiasaan makan, merokok, alkohol, tingkat aktivitas. Merokok masih merupakan hal yang kontroversial sebagai salah satu faktor risiko terhadap kelebihan berat badan.Tujuan penelitian ini adalahmengidentifikasi hubungan antara kebiasaan merokok dengan prevalensi obesitas dan overweight pada karyawan universitas di Jakarta. Disain penelitian adalah cross- sectional untuk mengetahui pengaruh antara kebiasaan merokok terhadap kelebihan berat badan.Kebiasaan merokok diukur dengan kuisioner; kelebihan berat badan diukur dengan IMT (Indeks Massa Tubuh).Dari total 80 responden,12 orang (15\%) memiliki kebiasaan merokok. Pada 12 orang perokok, didapatkan 2 orang (16,7\%) overweight dan 9 orang (75\%) obesitas. Pada responden perokok, risiko overweight dan obesitas masing- masing 1,6 kali dan 1,3 kali lebih besar daripada risikonya pada yang bukan perokok. Namun, pada penelitian ini tidak tercapai kemaknaan secara statistik $(p>0,05)$. Walaupun tidak didapatkan kemaknaan statistik, namun kebiasaan merokok menunjukkan indikasi sebagai faktor risiko kelebihan berat badan. Dibutuhkan penelitian lebih lanjut dalam skala lebih besar dengan mengikutsertakan kemungkinan pengaruh faktor lainnya.
\end{abstract}

Kata Kunci : Obesitas, Overweight, Status Gizi, Merokok, Karyawan

\section{PENDAHULUAN}

Obesitas dan overweight merupakan masalah kesehatan yang berisiko meningkatkan angka kesakitan dan kematian (Guh et al., 2009).Hal ini dikarenakan obesitas dapat meningkatkan insiden komorbid terhadap penyakit lain seperti diabetes mellitus, penyakit jantung, stroke, hipertensi dan kanker.National Institute of Diabetes and Digestive and Kidney Diseases (NIDDK) tahun 2012menyatakanbahwa overweight merujuk pada kelebihan berat badan yang berasal dari otot, tulang, lemak dan air, sedangkan obesitas merujuk pada kelebihan lemak tubuh. Obesitas ini terjadi karena dua faktor yaitu peningkatan massa jaringan adiposa dan peningkatan sekresi produk patogen yang menyebabkan pelebaran sel (Bray, 2004).

Penyebab dari obesitas atau overweight ini akibat dari ketidakseimbangan energi. Energi yang berasal dari makanan harus seimbang dengan yang dibakar oleh tubuh.ketika kalori yang masuk ke tubuh lebih banyak daripada yang dibakar maka akan terjadi penambahan berat badan, overweight, obesitas. Banyak faktor risiko yang meyebabkan ketidakseimbangan energi ini seperti, genetik, gaya hidup (kebiasaan makan, merokok), emosi, faktor ekonomi. Dampak kesehatan dapat terjadi diabetes tipe 2, penyakit jantung, hipertensi, perlemakan hati, osteoarthritis, kanker (payudara, kolon), stroke (NIDDK, 2012).

Menurut data Centers for Disease control and Prevention $(C D C)$, di dunia orang dewasa berusia mengalami overweight dan obesitas sebesar 68,8\%. Prevalensi antara laki-laki dengan perempuan hampir sama yaitu sekitar 36\%. Berdasarkan data World Health Organization (WHO) tahun 2014, 1,9 milyar orang dewasa $>18$ tahun mengalami overweight dan lebih dari 600 juta orang mengalami obesitas (Gasperin et al., 2014a).

Studi tahun 2008 diAsia Tenggara menunjukkan Malaysia merupakan negara dengan prevalensi obesitas tertinggi sebesar 14,4\%, diikuti Thailand ( 8,8\%), sedangkan prevalensi di Indonesia 
berkisar 5\% (Cheong, 2014)(Aizawa\& Helble, 2016). Studi lain tahun 2013 menunjukkan prevalensi overweight berkisar antara 4,9\% di Timor Leste sampai dengan 46,3\% di Malaysia, sedangkan prevalensi obesitas antara 1,6\% di Vietnam sampai 14,2\% di Malaysia (Dare\& Pell, 2015a). Kebiasaan merokok pada usia $>15$ tahun meningkat dari 34.2\% tahun 2007 menjadi $36.3 \%$ di tahun 2013 , dengan laki-laki sebesar $64,9 \%$ dan perempuan $2,1 \%$.

Suatu studi di Skotlandia menunjukkan perokok lebih berisiko untuk mengalami overweight dibandingkan bukan perokok (Mackay et al.,2013)(Addo, et al.,2015). Studi Firmingham menunjukkan angka harapan hidup pada perokok obesitas lebih pendek 13 tahun dibanding tidak obesitas dan tidak merokok.Merokok merupakan faktor risiko yang dapat dicegah terhadap terjadinya kanker, penyakit jantung dan paru.Bila dibandingkan antara laki-laki perokok dengan IMT normal maka yang obesitas lebih berisiko terhadap peningkatan angka kematian (Neovius et al., 2009).

Adapun tujuan dari penelitian yaitu mencari pengaruh dari kebiasaan merokok terhadap status gizi karyawan universitas di Jakarta. Diharapkan dari penelitian dapat mengidentifikasifaktor risiko yang berpotensi meningkatkan IMT sehingga dapat dilakukan langkah promotif dan preventif yang berdampak pada timbulnya penyakit lain.

\section{METODE PENELITIAN}

\section{Disain penelitian}

Penelitian ini bersifat observasional menggunakan disain cross sectional dengan panduan pengisian kuisioner dan pengukuran berat badan serta tinggi badan pada para karyawan Universitas Jakarta.

\section{Sampel}

Responden penelitian adalah karyawan Universitas di Jakarta dari berbagai disiplin ilmu yang berusia 21- 61 tahun.Data primer dari total responden sebesar 80 orang dari minimal 60 orang. Pengambilan sampel dengan metode convenientnon random sampling, denganmengikutsertakan seluruh responden yang bersedia mengisi kuisioner dan dilakukan pengukuran.

\section{Variabel penelitian}

Data kebiasaan merokok diperoleh melalui pengisian kuisioner. Pengukuran tinggi dengan stadiometer (stature meter 2M). Tiap responden melepas alas kaki, berdiri dengan kaki rapat, bahu sejajar serta tumit, punggung atas tegak lurus. Hasil ukur dalam centimeter dan diubah ke dalam meter. Berat badan diukur dengan timbangan ( merkcamry)dengan kapasitas maksimal $150 \mathrm{~kg}$. Tiap responden diukur dengan melepas alas kaki, berdiri dengan kaki rapat dan bahu sejajar. IMT diukur dengan kriteria WHO dengan rumus: berat badan (dalam $\mathrm{kg}$ )/tinggi badan (dalam $\left.\mathrm{m}^{2}\right)$ : underweight $\left(<18,5 \mathrm{~kg} / \mathrm{m}^{2}\right)$, normal $\left(18,5-24,99 \mathrm{~kg} / \mathrm{m}^{2}\right)$, overweight $\left(25-29,99 \mathrm{~kg} / \mathrm{m}^{2}\right)$, obesitas $\left(\geq 30 \mathrm{~kg} / \mathrm{m}^{2}\right)$. Variabel lainnya, yaituusia, jenis kelamin, status pernikahan, lama kerja, bagian kerja diperoleh dari kuisioner.

\section{Analisis statistik}

Analisis menggunakan SPSS 22.Kebiasaan merokok merupakan variabel independen, dibagi atas merokok dan tidak merokok. Status gizi merupakan variabel dependen.Usia dibagi menjadi $\leq 45$ tahun dan $>45$ tahun. Jenis kelamin dibagi atas perempuan dan laki-laki.Status pernikahan dibagi atas menikah atau tidak menikah.Lama bekerjadibagi atas 2 yaitu $\leq 15$ tahun dan $>15$ tahun. Bagian kerja terbagi atas administrasi, dosen, IT(programmer), teknisi, keamanan, 
instruktur olahraga.Prevalence Ratio(PR) dihitung untuk mengetahui risiko obesitas atau overweight terhadap status gizi normal pada perokok dibandingkan dengan yang bukan perokok. Kemaknaan statistik dinyatakan bila $\mathrm{p}<0,05$ dengan uji Fisher- exact.

\section{HASIL PENELITIAN}

Dari hasil penelitian diperoleh jumlah total 80 orang responden, dengan 50 responden $(67,5 \%)$ berusia $\geq 45$ tahun, dengan responden termuda berusia 21 tahun dan tertua berusia 71 tahun.Dari 80 responden, 43 orang $(53,8 \%)$ diantaranya laki-laki,responden dengan status menikah 75 responden $(93,8 \%)$. Sebaran okupasi menunjukkan sebagian besar responden di bidang administrasi yaitu 68 orang (85\%) dengan lama bekerja $>15$ tahun juga mencapai 68 responden (85\%). Responden dengan status gizi normal 18 orang ( $22,5 \%)$ dan overweight 17 responden $(21,3 \%)$, obesitas 45 responden (56,3\%).Pada penelitian ini tidak ada responden dengan status gizi underweight.

Responden dengan kebiasaan merokok sebanyak 12 orang (15\%) dari total 80 responden.Pada 12 orang yang merokok, didapatkan 2 orang $(16,7 \%)$ yang mengalami overweight dan 9 orang (75 \%) obesitas.(Gambar 1)

Pada penelitian ditemukan bahwa secara statistik tidak terdapat hubungan yang bermakna antara kebiasaan merokok dengan terjadinya obesitas atau overweight. Namun, dari penelitian ini didapatkan hasil bahwa pada responden merokokmemiliki risiko 1,6 kali lebih besar mengalami overweight daripada yang tidak merokok. Selain itu, didapatkan hasil juga bahwa responden merokok memiliki risiko 1,3 kali lebih besar mengalami obesitas daripada yang tidak merokok.

Tabel 1 Sebaran Karakteristik Responden Berdasarkan Usia, Jenis Kelamin, Status Pernikahan, Lama Kerja, Bagian Kerja.

\begin{tabular}{lcc}
\hline \multicolumn{1}{c}{ Variabel } & Frekuensi (n) & Persentase $(\%)$ \\
\hline Usia ( tahun) & & \\
$\leq 45$ & 30 & 32,5 \\
$>45$ & 50 & 67,5 \\
Jenis Kelamin & & \\
Laki-laki & 43 & 53,8 \\
Perempuan & 37 & 46,3 \\
Status Pernikahan & & \\
Tidak menikah & 5 & 6,3 \\
Menikah & 75 & 93,8 \\
Lama Bekerja & & \\
$\leq 15$ tahun & 12 & 15 \\
$>15$ tahun & 68 & 85 \\
Bagian Kerja & & \\
Administrasi & 68 & 85 \\
Dosen & 4 & 5 \\
IT (programmer) & 2 & 2,5 \\
Teknisi & 2 & 2,5 \\
Keamanan & 2 & 2,5 \\
Instruktur Olahraga & 2 & 2,5 \\
\hline
\end{tabular}




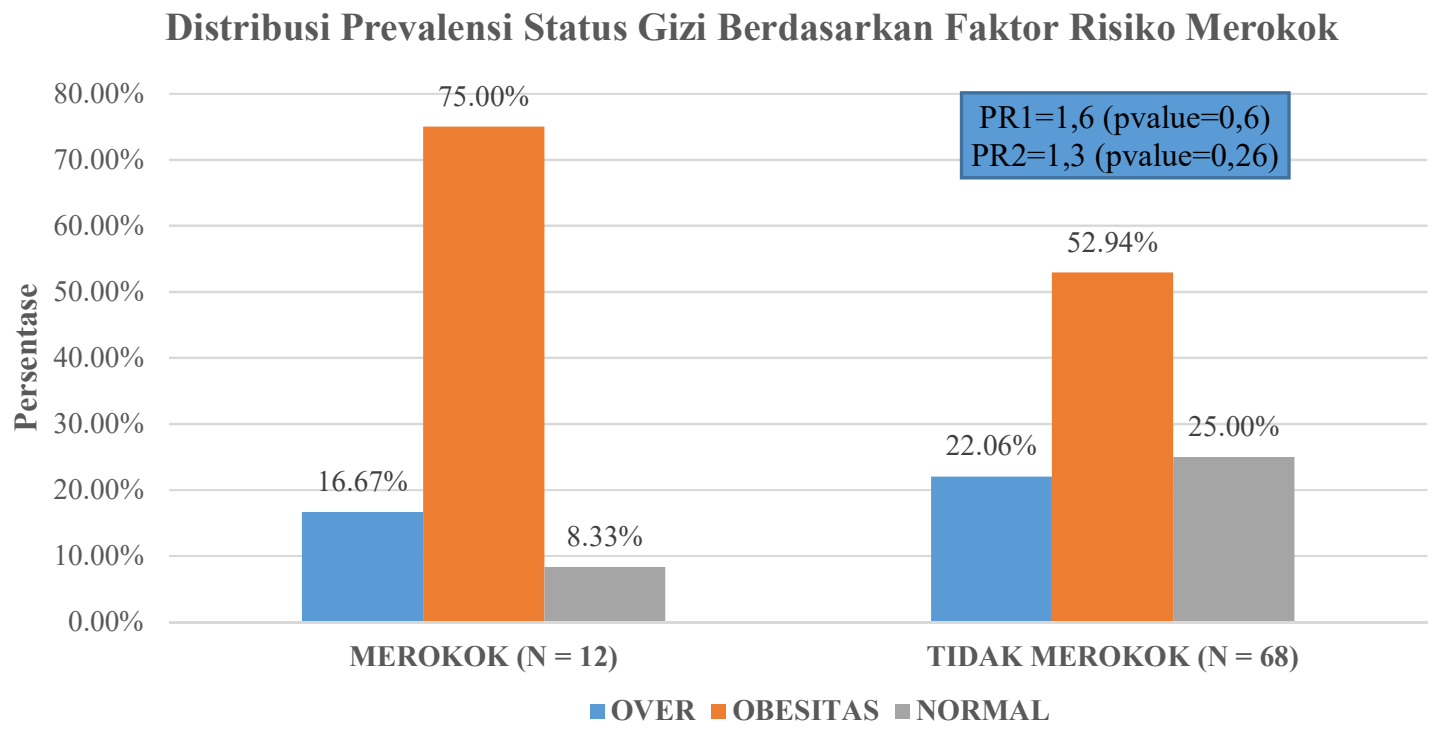

Gambar 1.Distribusi prevalensi status gizi berdasarkan faktor risiko merokok

\section{Keterangan:}

* Prevalence ratio1 (PR1) adalah besarnya risiko efek overweight pada responden yang merokok dibandingkan dengan besarnya risiko efek yang sama pada responden yang tidak merokok.

* Prevalence ratio 2 (PR2) adalah besarnya risiko efek obesitas pada responden yang merokok dibandingkan dengan besarnya risiko efek yang sama pada responden yang tidak merokok.

\section{PEMBAHASAN}

Hasil penelitian ini menemukan tidak ada hubungan yang bermakna antara kebiasaan merokok dengan obesitas ataupun overweight. Hal ini sejalan dengan penelitian Gasperin, bahwa tidak ada hubungan antara perokok dengan status gizi, Namun apabila pada perokok tersebut ditambahkan jumlah rokok yang dikonsumsi perhari maka didapatkan hubungan yang bermakna antara perokok dengan peningkatan berat badan $(p=0,001)$ dan IMT $(p=0,009)$. Pada penelitian ini tidak dinilai karakteristik dari merokok yaitu jumlah rokok perhari ataupun penggolongan jenis perokok.

Berdasarkan penelitian Plurphanswat \& Rodu, justru menemukan hubungan bermakna antara merokok dengan IMT yang rendah (underweight) dan normal, namun peningkatan IMT akan cenderung terjadi pada perokok saat berhenti merokok.Pada penelitian ini tidak memiliki responden dengan IMT underweight sehingga tidak dapat dilakukan analisis lebih jauh.Pada penelitian ini tidak menyetarakan berbagai faktor lain juga memengaruhi terjadinya overweight dan obesitas seperti intake makanan, exercise responden, konsumsi rokok, ataupun riwayat penyakit lainnya yang dapat berperan sebagai faktor perancu.

Penelitian ini, menggunakan desain cross-sectionalsehingga membatasi kemampuan menilai hubungan temporal sebab akibat antara kebiasaan merokok dengan obesitas atau overweight.Selain itu, metode convenient sampling yang mengambil seluruh responden tanpa pembatasan kriteria dapat menyebabkan distribusi faktor risiko dan penyakit pada sampel belum tentu mutlak mewakili kondisi sesungguhnya di populasi.Kemaknaan statistik yang tidak tercapai pada penelitian ini kemungkinan karena distribusi sampel perkelompok yang kurang 
seimbang sebagai fenomenal umum dari desain cross-sectional, dan kemungkinan pengaruh faktor risko lain yang belum diteliti.Sekalipun demikian, hasil penelitian ini yang menunjukkan merokok sebagai faktor risiko potensial dari kelebihan berat badan dapat tetap dipertimbangkan dengan mengacu pada nilai risiko epidemiologis (PR).

\section{KESIMPULAN}

Penelitian ini menunjukkan bahwa secara statistik tidak terdapat hubungan antara kebiasaan merokok dengan terjadinya overweight ataupun obesitas. Pada perokok, risiko terjadinya overweight lebih besar bila dibandingkan yang obesitas. Penelitian ini merupakan preeliminary study pada penelitian selanjutnya dengan skala yang lebih besar serta memerhatikan factor lainnya. desain lain.

\section{Ucapan Terima Kasih}

Peneliti mengucapkan terima kasih kepada: seluruh Tim PKM “ Peduli Kesehatan Jantung” FK UNTAR terutama Dr.dr.Meilani Kumala.,Sp.GK; dr.Sari Maryati Dewi, M.Biomed; dr.Alex Santoso, M.Gizi; dr. Susy Olivia, M.Biomed, dr. Ria Buana, M.Biomed yang memfasilitasi dalam pengambilan data serta dr. Marcella E. Rumawas, MS, PHddalam membantu analisis dan intepretasi data.

\section{REFERENSI}

Addo PNO, Nyarko KM, Sackey SO, Akweongo P, Sarfo B. ( 2015). Prevalence of obesity and overweightand associated factors among financial institution workers in Acra Metropolis, Ghana: a cross sectional study. BMC Res Notes, 8 (599).DOI 10.1186/s13104-015-590-1.

Aizawa T, Helble M. (2016). Rapid growth of overweight and obesity in Indonesia: Increasing risk for the poor. Retrieved from: http://www.asiapathways-adbi.org/2016/03/rapidgrowth-of-overweight-and-obesity-in-indonesia-increasing-risk-for-the-poor/

Bray GA. (2004). Medical Consequences of Obesity.The Journal of Clinical Endocrinology\& Metabolics, 89 (6): 2583-2586. DOI: 10.1210/jc.2004-0535.

Cheong WS. (2014). Overweight and Obesity in Asia. Gen Re. Retrieved from: http://www.genre.com/knowledge/publications/uwfocus14-2-cheong-en.html

Dare S, Mackay DF, Pell JP. ( 2015 a\&b). Realtionship between Smoking and Obesity: A CrossSectional Study of 499.504 Middle-Aged Adults in the UK General Population. PlosOne. DOI: 10.1371/journal.pone.0123579.

Gasperin LOF, Neuberger M, Tichy A, Moshammer. (2014a \&b). Cross-sectional association between cigarette smoking and abdominal obesity among Austrian bank employees. $B M J$ Open, 4:e004899. DOI: 10.1136/bmjopen-2014-0044899.

Guh DP, Zhang W, Bansback N, Amarsi Z, Birmingham L, Anis AH, (2009). The Incidence of co-morbidities related to obesity and overweight: A systematic review and meta- analysis. BMC Public Health, 9(88). DOI: 10.1186/1471-2458-9-88.

Mackay DF, Gray L, Pell JP. (2013). Impact of smoking nd smoking cessation on overweight and obesity: Scotland-wide, cross-sectional study on 40,036 participants. BMC Public Health, 13: 348. Retrieved from http://www.biomedicentral.com/1471-2458/13/348.

National Institute of Diabetes and Digestive and Kidney Diseases. (2012). Overweight and Obesity Statistics: Author. 
Neovius M, Sundstrom J, Rasmussen F. (2009). Combined effects of overweight and smoking in late adolescence on subsequent mortality: nationwide cohort study. BMJ 2009;338:b496. DOI: $10.1136 / \mathrm{bmj} . \mathrm{b} 496$.

Plurphanswat N, Rodu B. (2014a\& b). The Association of smoking and demographic characteristic on body mass index and obesity among adults in the U.S., 1999-2012. BMC Obesity, 1:18. Retrieved from http://www.biomedicentral.com/2052-9538/1/1/18. 